\title{
The Influence of Grinding Process and Drag Finishing ON THE MiLling TOOLS MACRO GEOMETRY
}

\author{
Boris Pätoprstý, Peter Pokorný, Marek Vozár, Tomáš Vopát \& Ivan Buranský
}
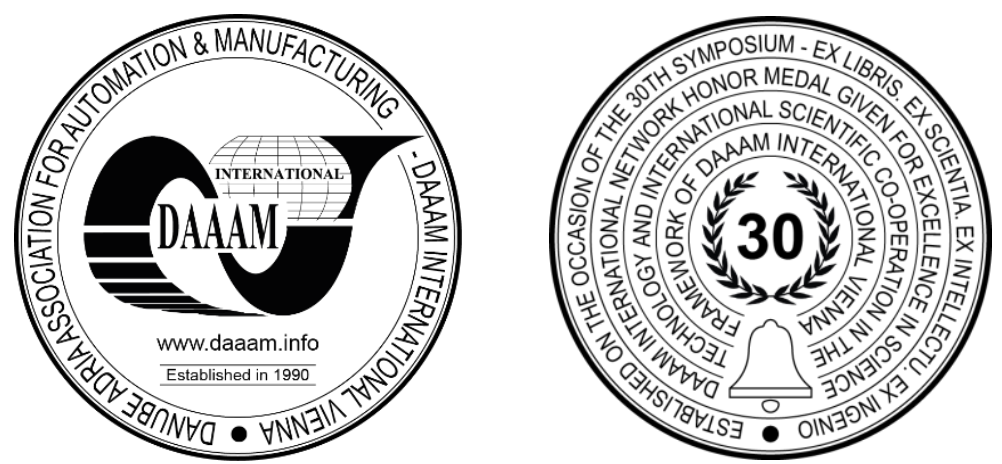

This Publication has to be referred as: Patoprsty, B[oris]; Pokorny, P[eter]; Vozar, M[arek]; Vopat, T[omas] \& Buransky, I[van] (2019). The Influence of Grinding Process and Drag Finishing on the Milling Tools Macro Geometry, Proceedings of the 30th DAAAM International Symposium, pp.1008-1013, B. Katalinic (Ed.), Published by DAAAM International, ISBN 978-3-902734-22-8, ISSN 1726-9679, Vienna, Austria

DOI: $10.2507 / 30$ th.daaam.proceedings. 140

\begin{abstract}
The paper deals with the comparison of milling tools geometry after drag finishing with various times. The aim was to determine the influence of drag finishing on macro geometry of the solid cemented carbide mills. The article describes tool geometry deviance after grinding process and the influence of drag finishing on rake angle, flank angle and diameter of the tools. The cemented carbide material with chemical composition WC + Co (10\%) was used for this research. The tools were manufactured on the Reinecker WZS 60 grinding machine from cemented carbide rod. The tool geometry of cutting tools was measured on ZOLLER genius 3 optical measuring machine. The drag finishing process was carried out on OTEC DF-3 Tools drag finishing machine with OTEC SIX 70/16 grinding granulate. It was found the accuracy of cutting tools manufactured on grinding machine, and the deviation of rake and flank angles was $2^{\circ}$ and tool diameter was $0.08 \mathrm{~mm}$.
\end{abstract}

Keywords: cutting tools; drag finishing; tool geometry; tools grinding

\section{Introduction}

Geometry of cutting tools is the main factor of tool performance and suitability for machining specific materials. A precise and regularly shaped cutting edge is important to accurate machining performance [1]. The required geometry of a cutting tool is obtained using grinding process [2]. The shape of the removed material from the blank corresponds to the shape of the envelope surface that results from the relative motion between the grinding wheel and workpiece [3]. In general the grinding of solid cemented carbide end mills can be divided into two parts, end and flute [4]. The main problem of this grinding operation is the achievement of the desired flute profile because this operation is characterized by complex contact between the blank and grinding wheel [3]. There are several factors which impact the accuracy and the quality of the manufactured cutting tools. The strength, hardness, and fracture toughness of the work material are the govering factors that control the extent of brittle fracture and plastic deformation [5]. High grinding force and heat the generation of thermal racks on the ground surface, and the wheel wear are becoming problems. It is important to keep the grinding temperature low in order to maintain good grinding conditions, to achieve this is generally recommended to select a low wheel speed to reduce the generation of grinding heat [6]. Heat generated in the contact area between a wheel and a workpiece is the main cause of the deterioration in the metallurgical properties of the workpiece, dimensional accuracy 
and wheel life [7]. Next factor which influenced grinding process negatively is wheel wear. The axial feed speed has a positive effect of the wheel wear and the cutting speed has negative effect of the wheel wear. Farsky et. al investigated that wheel wear influenced the cutting tool roughness negatively [8]. The profitability can be achieved with low cutting speeds and high axial feed rate [9].

Also grain size of grinding wheels affected the process. The big engagement of the high number of active grains means a reduction of the mechanical treatment by each single grain, because the same material is removed by higher number of active grains. The lower load on the cutting edge leads to better cutting edge qualities [1]. Small grains has positive effect of cutting edge chipping. This effect is highly significant [9]. The grinding process and the resulting surface are affected by the grain size of the cemented carbide. Experiment of Baksa showed that different quality of the cutting edge after grinding has a little effect on the cutting tool life [2]. The cutting edge geometry and the applied edge preparation methods affect the tool wear of cutting tools [10]. Cutting edge can be prepared with several methods of cutting edge preparation after grinding. A certain number of important properties of the tool material such as hardness, strength, temperability and thermal conductivity are required to ensure a long lifetime of cutting tools [11]. There are several publications which investigated the influence of tool geometry on the tool wear [12], [13]. Issue of edge preparation affecting the macro geometrical properties of cutting tools, was not thoroughly investigated, that is why the following research has been carried out. The purpose of this article was to determine the accuracy of solid cemented carbide mills manufactured on Reinecker WZS 60 grinding machine and determine the influence of drag finishing on macro geometry of solid cemented carbide mills.

\section{Materials and methods}

The solid cemented carbide mills made of cemented carbide with grade of CTS20D by the Ceratizit Company (K20K40 by ISO) were used in this article. This cemented carbide material with content of Co of $10 \%$ and achieved hardness of 1580 by Vickers was used. As a workpiece for manufacture solid cemented carbide mills was used cemented carbide rod. The Wire Electrical Discharge Machining method was used to make workpieces with dimension $\varnothing 10 \mathrm{~h} 6$ x $85 \mathrm{~mm}$.

The solid cemented carbide mills will be used for milling difficult-to-cut materials, especially for austenitic stainless steel. Cutting edge preparation process was carried out on these cemented carbide end mills to round the sharp cutting edge. Grinding machine Reinecker WZS 60 was used for manufacturing solid cemented carbide mills. Four grinding wheels from synthetic diamond by the producer URDIAMANT Slovakia s.r.o. were used to manufacture the tools. Grain size of grinding wheels was D64 by ISO 6106, which mean that the average grain size was from $50-62 \mu \mathrm{m}$. Different grinding wheels were used to manufacture the flute of the tool and also the end of the tools (Table 1). NUMROTOplus software was used to create NC code for grinding machine.

\begin{tabular}{|c|c|c|c|c|}
\hline $\begin{array}{c}\text { Grinding } \\
\text { wheels type }\end{array}$ & $\begin{array}{c}\text { Diameter } \\
{[\mathrm{mm}]}\end{array}$ & $\begin{array}{c}\text { Spindle rotation } \\
\text { speed }\left[\mathrm{min}^{-1}\right]\end{array}$ & $\begin{array}{c}\text { Grinding speed } \\
{\left[\mathrm{m}_{\mathrm{min}} \mathrm{min}^{-1}\right]}\end{array}$ & Operation type \\
\hline $1 \mathrm{~V} 1$ & 100 & 3634 & 19,02 & Flute of the tool \\
\hline $1 \mathrm{~A} 1$ & 75 & 3634 & 14,21 & Flute of the tool \\
\hline $11 \mathrm{V9}$ & 100 & 4750 & 29,29 & Flank faces \\
\hline $12 \mathrm{~V} 9$ & 125 & 3058 & 20 & End of the tool \\
\hline
\end{tabular}

Table 1. Grinding wheels used to manufacture the solid cemented carbide mills

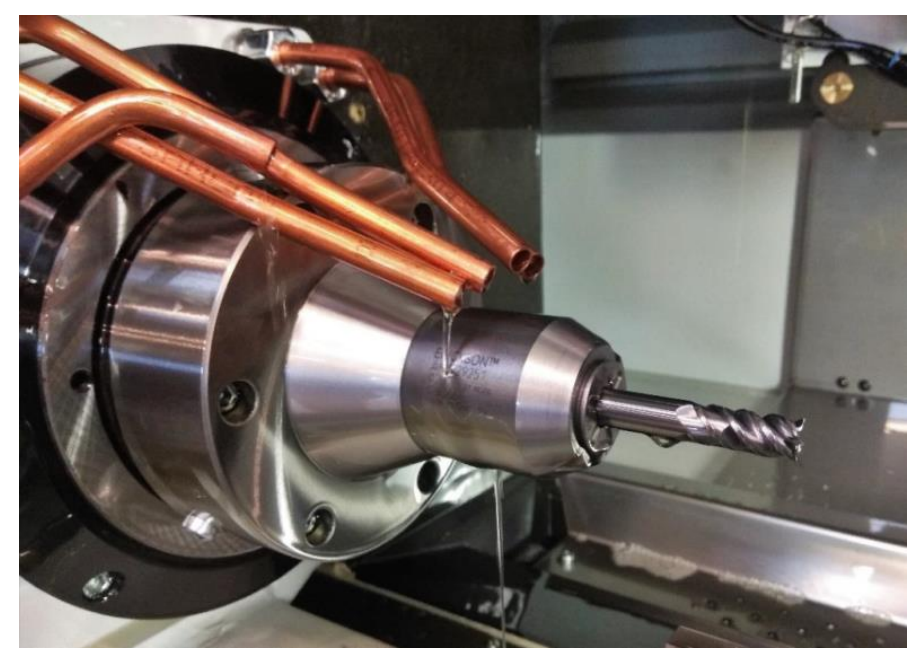

Fig. 1. Grinding of the solid cemented carbide mills 


\begin{tabular}{|l|c|}
\hline Cutting length $[\mathrm{mm}]$ & 15 \\
\hline Diameter of the tool $[\mathrm{mm}]$ & 9,970 \\
\hline Core diameter $[\mathrm{mm}]$ & 5 \\
\hline Helix angle $\left[{ }^{\circ}\right]$ & 28,202 \\
\hline Flank angle $\alpha$ (on helix) $\left[{ }^{\circ}\right]$ & 9 \\
\hline Flank angle $\left.\alpha{ }^{\circ}\right]$ & 8 \\
\hline Rake angle $\gamma\left[{ }^{\circ}\right]$ & 8 \\
\hline
\end{tabular}

Table 2. Input parameters of manufacturing solid cemented carbide mills

Cutting edge preparation was used to make the rounded cutting edge on grinded solid cemented carbide mills. Drag finishing was chosen for edge preparation and the drag finishing machine was by German producer OTEC model DF-3 Tools. Grinding granulate OTEC SIX 70/16 with OTEC HL 06 grinding oil was used for drag finishing process. The time of drag finishing was 15 minutes, while 7,5 minutes the solid cemented carbide mills rotated clockwise and the other 7.5 minutes rotated counter-clockwise. Reached radius of cutting edge was $15 \mu \mathrm{m}$.

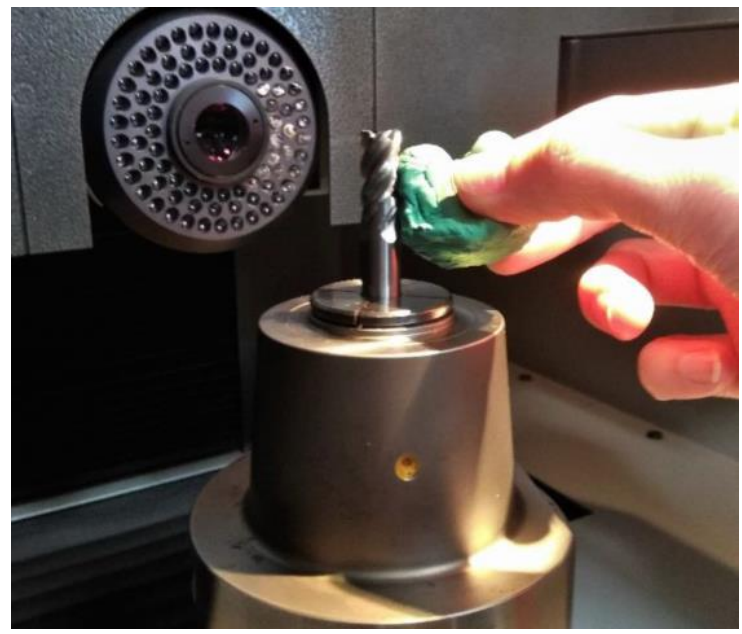

Fig. 2. Measuring of the solid cemented carbide mills

ZOLLER genius 3 measuring machine was used to measure macro geometry of grinded solid cemented carbide mills before and after drag finishing. ZOLLER genius 3 machine is provided with adjustable angle of inclination of measuring camera. Flank and rake angle on the end of the tool, flank angle on the helix, helix angle and core and tool diameter were the parameters which were measured. Ten grinded solid cemented carbide mills and six drag finished solid cemented carbide mills were measured and their macro geometry was compared.

\section{Results and discussion}

In this experiment the macro geometry of solid cemented carbide mills after grinding and drag finishing was evaluated. Following parameters were evaluated: flank and rake angle, core diameter and tool diameter and helix angle. ZOLLER GENIUS 3 measuring machine was used to measure these parameter of the solid cemented carbide mills. Macro geometry of ten solid cemented carbide mills was compared and there was examined how the parameters of milling tools were varied. In the following table can be seen the parameters of solid cemented carbide mills.

\begin{tabular}{|c|c|c|c|c|c|c|}
\hline $\begin{array}{c}\text { Tool } \\
\text { number }\end{array}$ & $\begin{array}{c}\text { Rake } \\
\text { angle } \gamma \\
{\left[{ }^{\circ}\right]}\end{array}$ & $\begin{array}{c}\text { Flank } \\
\text { angle } \alpha \\
{\left[{ }^{\circ}\right]}\end{array}$ & $\begin{array}{c}\text { Flank } \\
\text { angle } \alpha \\
(\text { on helix }) \\
{\left[{ }^{\circ}\right]}\end{array}$ & $\begin{array}{c}\text { Core } \\
\text { diameter } \\
{[\mathrm{mm}]}\end{array}$ & $\begin{array}{c}\text { Helix } \\
\text { angle }\left[{ }^{\circ}\right]\end{array}$ & $\begin{array}{c}\text { Tool } \\
\text { diameter } \\
{[\mathrm{mm}]}\end{array}$ \\
\hline 1 & 8 & 6.71 & 9.69 & 4.981 & 28.197 & 9.944 \\
\hline 2 & 6.69 & 7.48 & 9.95 & 4.965 & 28.181 & 9.948 \\
\hline 3 & 6.75 & 7.66 & 9.91 & 4.961 & 28.201 & 9.944 \\
\hline 4 & 6.12 & 7.12 & 8.96 & 4.94 & 28.169 & 9.951 \\
\hline 5 & 7.35 & 7.54 & 8.92 & 4.951 & 28.199 & 9.957 \\
\hline 6 & 7.25 & 5.93 & 9.62 & 4.939 & 28.212 & 9.957 \\
\hline 7 & 8.1 & 6.87 & 9.01 & 4.967 & 28.226 & 9.947 \\
\hline 8 & 6.67 & 7.43 & 9.16 & 4.952 & 28.188 & 9.954 \\
\hline
\end{tabular}




\begin{tabular}{|c|c|c|c|c|c|c|}
\hline 9 & 7.22 & 7.03 & 9.91 & 4.941 & 28.176 & 9.958 \\
\hline 10 & 7.26 & 7.48 & 9.87 & 4.962 & 28.199 & 9.944 \\
\hline
\end{tabular}

Table 3. Macro geometry of to solid cemented carbide mills after grinding

From the table 3 can be seen how the parameters of the solid cemented carbide mills were varied. Rake angle and tool angle on the end and helix had the biggest differences, while the minimum rake angle on the end was $6.12^{\circ}$ and the maximum angle was $8.1^{\circ}$, so the difference between the rake angle was $1.98^{\circ}$. The difference between flank angle on the end was $1.73^{\circ}$ and the difference between flank angle on helix was $1.03^{\circ}$. The differences between other parameters was considerably small and in case of core diameter it was $0.042 \mathrm{~mm}$ in case of helix angle it was $0.057^{\circ}$ and in case of tool diameter it was $0.014 \mathrm{~mm}$.

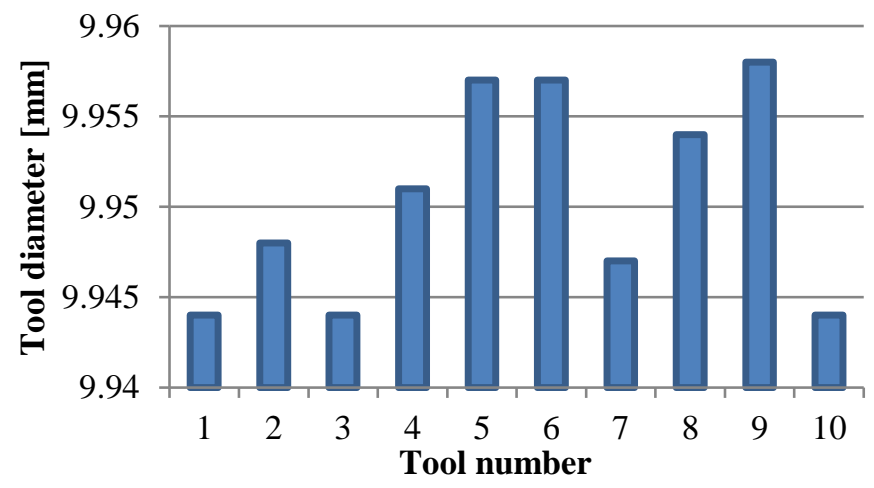

Fig. 3. Tool diamater of the solid cemented carbide mills after grinding

The geometry parameters of solid cemented carbide mills after drag finishing are shown in table 4 . From the table can be seen that the parameters of milling tools varied and the most differences were in case of rake and flank angle on the end of the tool and flank angle on the helix of the tool. Differences between rake angle was $1.29^{\circ}$. flank angle was $1.34^{\circ}$ and flank angle on the helix was $0.86^{\circ}$. The differences between other parameters were only $0.1^{\circ}$ or less than 0.1 $\mathrm{mm}$.

\begin{tabular}{|r|l|r|r|r|r|r|r|}
\hline $\begin{array}{l}\text { Tool } \\
\text { number }\end{array}$ & $\begin{array}{l}\text { Cutting } \\
\text { edge } \\
\text { preparation } \\
\text { time }[\mathrm{min}]\end{array}$ & $\begin{array}{c}\text { Rake } \\
\text { angle } \gamma \\
{\left[{ }^{\circ}\right]}\end{array}$ & $\begin{array}{c}\text { Flank } \\
\text { angle } \alpha \\
{\left[{ }^{\circ}\right]}\end{array}$ & $\begin{array}{c}\text { Flank } \\
\text { angle } \alpha \\
(\text { on helix }) \\
{\left[{ }^{\circ}\right]}\end{array}$ & $\begin{array}{c}\text { Core } \\
\text { diameter } \\
{[\mathrm{mm}]}\end{array}$ & $\begin{array}{c}\text { Helix } \\
\text { angle }\left[{ }^{\circ}\right]\end{array}$ & $\begin{array}{c}\text { Tool } \\
\text { diameter } \\
{[\mathrm{mm}]}\end{array}$ \\
\hline 1 & 15 & 7.8 & 7.04 & 9.21 & 4.879 & 28.299 & 9.943 \\
\hline 2 & 15 & 7.23 & 7.37 & 9.02 & 4.888 & 28.223 & 9.943 \\
\hline 3 & 15 & 6.95 & 7.78 & 9.07 & 4.893 & 28.19 & 9.947 \\
\hline 4 & 15 & 7.76 & 8.38 & 9.85 & 4.926 & 28.19 & 9.939 \\
\hline 5 & 15 & 8.24 & 7.5 & 9.43 & 4.932 & 28.218 & 9.948 \\
\hline 6 & 15 & 6.97 & 7.68 & 8.99 & 4.953 & 28.221 & 9.955 \\
\hline
\end{tabular}

Table 4. Macro geometry of the solid cemented carbide mills after drag finishing
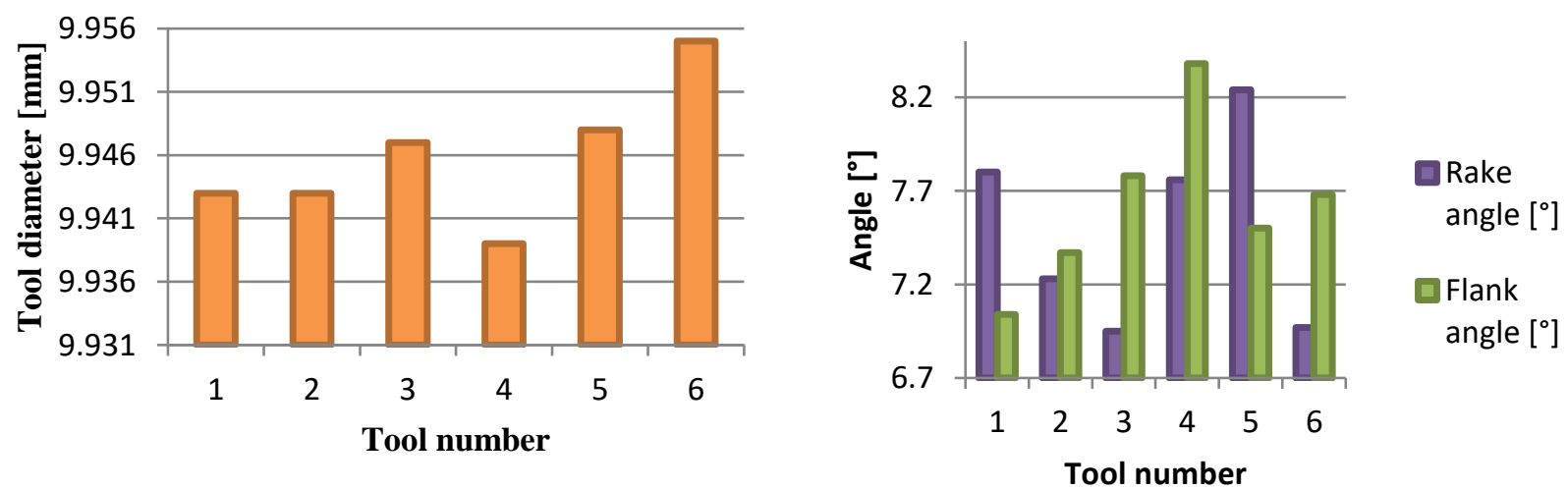

Fig. 4. Tool diameter and flank and rake angle of the tools after drag finishing 

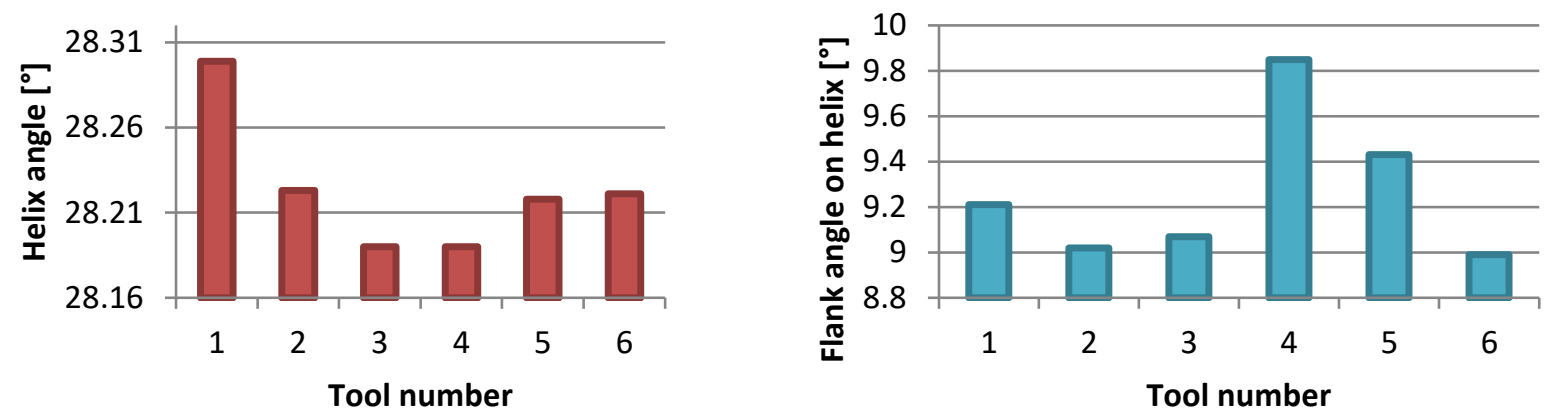

Fig. 5. Helix angle and flank angle on the helix of the tools after drag finishing

From previous tables with parameters of the solid cemented carbide mills after grinding and drag finishing can be seen that in both cases the parameters varied and mostly varied in case of flank and rake angles of mills. It has been found that the accuracy of the solid cemented carbide mills after grinding on grinding machine Reinecker WZS 60 is in deviation of $2^{\circ}$ for the tool angles (rake and flank) and $0.08 \mathrm{~mm}$ for the diameters of the tool (core and total). The inaccuracy could be caused by the thermal expansion in the grinding process, wheel wear or it could be caused by measurement uncertainty.

\section{Conclusion}

The paper presents how grinding process and drag finishing influence the macro geometry of solid cemented carbide mills. In this research more machines were used, at first to grind the cutting tools Reinecker WZS 60 grinding machine. NUMROTOplus software was used to create NC code for grinding machine. Manufactured tools were drag finished on OTEC DF-3 Tools drag finishing machine with OTEC SIX 70/16 grinding granulate. All the tools were measured on ZOLLER genius 3 measuring machine. There was investigated that the parameters of solid cemented carbide mills after grinding varied and the most significant differences were observed for flank and rake angles on the end of the tool and also on the helix. The difference ranges from $1.03^{\circ}$ to $1.98^{\circ}$. The difference of helix angle was only $0.057^{\circ}$ and the differences of diameters of the tool (core and total) were less than $0.05 \mathrm{~mm}$. After drag finishing the results were similar. The diameters of the tools varied less than $0.08 \mathrm{~mm}$. Differences of the helix angle was $0.1^{\circ}$. And the differences between flank and rake angles were from $0.86^{\circ}$ to 1.29 . So it can be stated that after drag finishing were the differences between the parameters of macro geometry of the tools smaller than the parameters before drag finishing. The differences between the parameters could be caused by wear of the grinding wheels, measurement uncertainty of the measuring machine and heat in the process and thermal expansion. Aim of the research was to determine the accuracy of the grinding machine. The accuracy of cutting tool grinded on grinding machine was in the deviation of $2^{\circ}$ for the tool angles and $0.08 \mathrm{~mm}$ for the diameter of the tools. The other purpose of this research was to determine if the drag finishing process influenced the macro geometry of the solid cemented carbide mills, so the result was that this process influenced the macro geometry negligibly, but the deviation of the geometry parameters was smaller than the geometry parameters before drag finishing. The assumption when grinding cutting tools is that with increasing number of manufactured tools the wear of the grinding wheel increases as well, resulting in linear change of the macro geometry parameters of the tools. However, behaviour like this was not observed during the research. It cannot be said if the grinding process in production of so few milling tools increased the size of the flank and rake angles or decreased these parameters. It is assumed that it could be seen in production of more milling tools. In future research we will determine the influence of drag finishing process, such as the methods of cutting edge preparation on tool wear, so the influence on macro geometry was determined in this research.

\section{Acknowledgments}

This work was supported by the Scientific Grant Agency of the Slovak Republic under the grant no. 1/0097/17 and the Slovak Research and Development Agency of the Slovak Republic under the Contract no. APVV-16-0057.

\section{References}

[1] Tönshoff, H. K \& Friemuth, T (200). In-process dressing of fine diamond wheels for tool grinding, Precision Engineering, Volume 24, Issue 1, Pages 58-61, ISSN 0141-6359

[2] Baksa, T; Schornik, V; Adamek, P \& Zetek, M (2016). Machining of Inconel 718 Using Uncoated Cutting Tools 6With Different Cutting Edge Quality, Proceedings of the 27th DAAAM International Symposium, pp.0441-0446, B. Katalinic (Ed.), Published by DAAAM International, ISBN 978-3-902734-08-2, ISSN 1726-9769, Vienna, Austria

[3] Karpuschewski, B; Jandecka, K \& Mourek, D (2011). Automatic search for wheel position in flute grinding of cutting tools, CIRP Annals, Volume 60, Issue 1, Pages 347-350, ISSN 0007-8506 
[4] Chen, Z; Ji, W; He, G; Liu, X; Wang, L \& Rong, Y (2018). Iteration based calculation of position and orientation of grinding wheel for solid cutting tool flute grinding, Journal of Manufacturing Processes, Volume 36, Pages 209215, ISSN 1526-6125

[5] Dobrescu, T. G; Pascu, N - E; Opran, C \& Bucuresteanu, A. M (2012). Annals of DAAAM for 2012 \& Proceedings of the 23rd International DAAAM Symposium, Volume 23, No.1, ISSN 2304-1382, ISBN 978-3-901509-91-9, CDROM version, Ed. B. Katalinic, Published by DAAAM International, Vienna, Austria,

[6] Kuriyagawa, T; Syoji, K \& Ohshita, H (2003). Grinding temperature within contact arc between wheel and workpiece in high-efficiency grinding of ultrahard cutting tool materials, Journal of Materials Processing Technology, Volume 136, Issues 1-3, Pages 39-47, ISSN 0924-0136

[7] Takashi, U; Masahiko, S; Tadaaki, S \& Kazuo N (1995), Thermal Behaviour of Cutting Grain in Grinding, CIRP Annals, Volume 44, Issue 1, Pages 325-328, ISSN 0007-8506

[8] Farsky, J; Zetek, M; Baksa, T \& Adamek, P (2017). Influence of Grinding Conditions on Surface Quality and Accuracy when Tool Grinder is Used, Proceedings of the 28th DAAAM International Symposium, pp.0930-0936, B. Katalinic (Ed.), Published by DAAAM International, ISBN 978-3-902734-11-2, ISSN 1726-9769, Vienna, Austria

[9] Denkena, B., Grove, T. \& Behrens, L (2015). Significant influence factors on the grinding tool wear and cutting mechanisms during grinding of PCBN inserts, Prod. Eng. Res. Devel. 9: 187. https://doi.org/10.1007/s11740-0150599-

[10] Vopat, T; Kuruc, M; Simna, V; Necpal, M; Buransky, I; Zaujec, R \& Peterka, J. (2018) The Influence of Cutting Edge Radius Size on the Tool Life of Cemented Carbide Drills, Proceedings of the 29th DAAAM International Symposium, pp.0421-0425, B. Katalinic (Ed.), Published by DAAAM International, ISBN 978-3-902734-20-4, ISSN 1726-9769, Vienna, Austria

[11] Jaworski, J., Trzepiecinski, T. \& Stachowicz (2016), Effect of Grinding Parameters on the Surface Quality of Cutting Tools Made of High-Speed Low-Alloy Steels F. Strength Mater 48: 566. https://doi.org/10.1007/s11223-016-9799-3

[12] Baksa, T; Hronek, O; Farsky, J \& Zetek, M (2017). Influence of Cutting Conditions on the Surface Quality and Grinding Wheel Wear During Cylindrical Grinding of Inconel 718, Proceedings of the 28th DAAAM International Symposium, pp.0500-0505, B. Katalinic (Ed.), Published by DAAAM International, ISBN 978-3-902734-11-2, ISSN 1726-9769, Vienna, Austria

[13] Dana, M; Zetek, M \& Schornik, V (2016). Effect of Cutting edge Geometry on Cutting Tool Life when Drilling Inconel 718, Proceedings of the 26th DAAAM International Symposium, pp.0709-0714, B. Katalinic (Ed.), Published by DAAAM International, ISBN 978-3-902734-07-5, ISSN 1726-9769, Vienna, Austria 